\title{
Methodology of Teaching Law Disciplines in Russian and English to Law Students: A Digital Form and Traditional Content
}

\author{
Polina E. Marcheva (Korotkova) ${ }^{1}$, Elena A. Kholina ${ }^{2}$ \\ ${ }^{1}$ Kutafin Moscow State Law University (MSAL), Moscow, Russia \\ ${ }^{2}$ Moscow Metropolitan Governance Yury Luzhkov University (MMGU), \\ Moscow, Russia
}

\begin{abstract}
The research problem addressed in this paper is to substantiate the most optimal forms and methods of teaching the law disciplines both in Russian and in English in a law school in the context of the introduction of digital forms of learning into traditional educational environment of a law school. The research applies the methods of the concept of professional training in advocacy. Professional training in advocacy is one of the practice-oriented areas of advocacy that includes the methodology of training students in a law school covering the statistical method, systematic method, historical and legal method, method of participatory observation, method of analysis and synthesis. The paper describes new areas of work and new opportunities that have become available to students in 2020-2021, including new master's programs and additional in-person and online courses of students' practice-oriented training. The paper examines how students of Kutafin Moscow State Law University (MSAL) can acquire necessary knowledge and practice skills in order to pass the qualification examination for the status of an advocate and be able to practice law in the Russian Federation and abroad. The authors of the paper believe that the development of digital technologies has made it possible to move to a qualitatively new level of teaching. Along with classical teaching methods, the faculty have started implementing digital technologies in the learning process, focusing on practice-oriented types of work, including practice-oriented projects. A partial transition to distance learning has contributed to creation and development of the common educational environment
\end{abstract}


that will enable international cooperation in student education and development of other digital environments, such as an integrated information system for the Russian Advocacy as well.

Keywords: legal education; distance learning; law clinic; learning in English; advocacy; Bar qualification examination; Russian legal education; statistical data

Acknowledgements: The reported study was funded by the Russian Foundation for Basic Research according to the research project № $18-29-16170 m k$.

Cite as: Marcheva (Korotkova), P.E. and Kholina, E.A., (2021). Methodology of Teaching Law Disciplines in Russian and English to Law Students: A Digital Form and Traditional Content. Kutafin Law Review, 8(4), pp. 690-712, doi: 10.17803/2313-5395.2021.4.18.690-712.

\section{Contents}

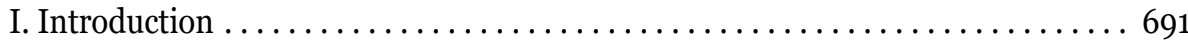

II. Methodology ......................................... 693

III. Methods of Teaching. .................................. 695

IV. Using Webinars in a Teaching Process: Pros and Cons . .............. 697

V. Peculiarities of Practice-Oriented Training and Teaching Aids' Preparation in Digital Era ........................................... 699

V.1. Interdisciplinary Approach to Training and Teaching Aids' Preparation. . . 699

V.2. Digital Educational Environment and Opportunities for Students...... 701 VI. Teaching Professional Skills in a Law Clinic.................... 703 VII. Using a Courtroom for Additional Purposes. ................... 706 VIII. Conclusion....................................... 709 References........................................ 709

\section{Introduction}

One of the most popular fields in higher education is law. University graduates with a law degree are able to carry out professional activities in different fields. Having gained necessary work experience in a legal field and complying with all other requirements established by law, 
lawyers take a qualification examination to acquire the status of an advocate $^{1}$ and start practicing law.

According to the statistical data provided by the Russian Federal Bar Association, in 2017 the number of applicants for the status of an advocate was 5,604. 5,376 candidates were admitted to take the Bar examination. 3,630 candidates (67.5 percent) were granted the advocate's status. In 2018, 5,345 candidates applied to acquire the status of an advocate. 5,113 candidates were admitted to take the Bar examination. 3,607 candidates (70.5 percent) acquired the status of an advocate. In 2019, the number of applicants to acquire the status of an advocate was 5,001. 4,839 of candidates were admitted to take the Bar examination, 3,336 candidates (68.9 percent) acquired the status of an advocate. In 2020, the number of applicants to acquire the status of an advocate decreased considerably and counted 4,173 candidates. 3,929 candidates were admitted to take the Bar examination, 2,585 candidates ( 65.8 percent) passed the examination successfully.

The data show that the number of candidates to take the Bar examination remained at approximately the same level. It is more likely that the decrease in the number of candidates who applied for the Bar examination in 2020 was caused by a total change in the society due to the influence of digital innovations introduced, among other reasons, due to the necessity to fight with the spread of new COVID-19 pandemic.

It is important to mention that, according to the data of the Public Registry of the Ministry of Justice of the Russian Federation as of November 2021, the number of advocates with the active status had not changed dramatically and amounted to 74,693 advocates. ${ }^{2}$ The Federal Chamber of Advocates of the Russian Federation publicized data according to which as of 31 December 2019 the number of practicing

${ }^{1}$ An advocate in the Russian Federation is a person having a degree in law who has received advocate's status and the right to practice law under the Federal Law No 63 dated 31.05.2002 "On Advocate's Activity and the Bar in the Russian Federation."

${ }^{2}$ On Advocacy in the Russian Federation: Information Portal of the Ministry of Justice of the Russian Federation. Available at: ttp://lawyers.minjust.ru/lawyers ?fullName $=$ \&registerNumber $=\&$ identityCard $=\&$ status $=1 \&$ orgForm $=\&$ reg $\quad[$ Accessed 04.11.2021] (In Russ.). 
advocates with the active status was 74,818 people. ${ }^{3}$ According to the data of the Public Registry of the Ministry of Justice of the Russian Federation, as of December 2020, the number of advocates with the active status has not changed dramatically and amounts to 74,661 people. ${ }^{4}$ According to the data of the Public Registry of the Ministry of Justice of the Russian Federation, as of September 2021, there are 226 foreign advocates who are engaged in professional activity in the Russian Federation; a big number of advocates provide professional help not only within the Russian Federation, but in other countries as well.

All of the above justify that the profession of an advocate is still in demand. Thus, any higher education institution, including Kutafin Moscow State Law University (MSAL), pursues two main goals. First, it is important to help law students to acquire necessary legal knowledge, to prepare for the qualification examination for the status of an advocate and to form professional skills necessary in a new digital reality. Second, universities have to let students acquire knowledge in a foreign language to enable them to practice law not only in the Russian Federation, but also abroad as "Modern society requires competitive professionals who can communicate in a professional foreign language in their specialty" (Demchenko, Gulieva, Larina and Simaeva, 2021, pp. 297-307).

\section{Methodology}

The methodology is two-fold. On the one hand, the authors refer to actual statistical data concerning advocates and their operation in the Russian law system. On the other hand, the authors rely on the methodological foundations developed by outstanding scholars.

Thus, advocacy studies were initiated at the Department of Advocacy, Kutafin Moscow State Law University (MSAL), and Prof.

3 The Russian Federation Bar Association. Information on the composition of the advocates' community in the Russian Federation for 2019. Available at: https://fparf.ru/practical-information/statistics/svedeniya-o-sostave-advokatskogosoobshchestva-v-rossiyskoy-federatsii-za-2019-god/ [Accessed 13.11.2021] (In Russ.).

4 On Advocacy in the Russian Federation: Information Portal of the Ministry of Justice of the Russian Federation. Available at: http://lawyers.minjust.ru/lawye rs?fullName $=$ \&registerNumber $=$ \&identityCard $=\&$ status $=1 \&$ orgForm $=\&$ reg $[$ Accessed 04.11.2021] (In Russ.). 
Yuriy F. Lyubshev, a holder of habilitation degree in Law, Professor of the Department of Advocacy, wrote the first textbook on advocacy law "The Course of Advocacy Law" (Lyubshev, 2003). In his textbook, Prof. Yuriy F. Lyubshev defined the subject matter of advocacy as a science in the system of other branches of legal knowledge, outlined the social and legal necessity to study advocacy and research further the subject matter under consideration, defined the importance of methodology in the study of advocacy, listed the key methods for the advocacy studies. He also determined the legal fundamentals of the Bar as an organization, legal status of advocacy and advocates. His methodological foundations are employed by the authors of this paper.

One of the directions of the scientific school of advocacy studies involved participation of the faculty of the Department of Advocacy in the formation and functioning of the inter-university scientific school that explored advocacy as an institution of a civil society. Another direction covered the legal theory of the attorney-client privilege developed by Prof. Yuriy S. Pilipenko, a holder of habilitation degree in Law. A practice-oriented direction of the scientific school of advocacy implemented by the Department of Advocacy provided for the concept of professional training of students encouraging them to pass the Bar examination to acquire the status of an advocate and to perform their professional activities. The concept includes scientific foundations of the methodology of professional training of students, advocates' assistants and trainees developed by the teaching staff of the Department of Advocacy.

Over the years under the supervision of the Department of Advocacy $36 \mathrm{PhD}$ theses (33) and doctoral dissertations (3) on advocacy have been prepared and successfully defended. All academic research papers were prepared within the framework of legal scientific specialty 12.00.11 "The Judicial Power, Prosecutor's Supervision, Organization of Law Enforcement Activities," the title that up to 2009 determined advocacy as a subject area of research. Currently, advocacy remains in the passport of the specialty, which allows considering the legal under consideration phenomena from the position of the corresponding scientific specialty. 


\section{Methods of Teaching}

Currently, law schools' faculties, including Kutafin Moscow State Law University (MSAL), continue to use classical teaching methods that are classified by researchers on various grounds. Thus, Alexander F. Kolotov and Ivan V. Skuratov offer the teaching methods classification based on the holistic approach to the learning process and divide all methods into three large groups: 1 . methods of organization and implementation of learning and cognitive activity; 2. methods of stimulation and motivation of learning and cognitive activity; 3. methods of control and self-control of learning and cognitive activity (Kolotov and Skuratov, 2014). Alternatively, Olga I. Shevchenko, Mikhail A. Volkov and Anastasia S. Prystavka focus on verbal methods, visual methods, practical methods and problem-based learning methods (Shevchenko, Volkov and Prystavka, 2018).

The totality of methods constitutes teaching methodology that in the present conditions should not only be practice-oriented and aimed at students' independent work and self-studying, but also it should also correspond to the requirements applied at the international level, since one of the main goals of developing international activities in education is to integrate Russia into the world educational community as an equal partner (Egorova and Minbaleev, 2021).

To this end, students are now offered, in addition to compulsory and variable subjects, additional disciplines, including subjects taught in English. By choosing these additional disciplines, students can acquire professional knowledge based on the principle of "internationalization of professional training of a specialist" (Yarotskaya and Moiseenko, 2021). This "principle has an integrative character and fixes an essential role of the 'foreign language' as an academic discipline in the formation of professional consciousness and worldview of an individual as a tool of his/her full professional self-realization" (Yarotskaya, 2013).

It is necessary to pay attention to the fact that "American professors note that training of lawyers from other legal systems (in particular, countries of civil law) faces serious methodological problems, and good knowledge of English does not guarantee students' success in their learning" (Abernathy, 2006). Therefore, in our opinion, there is a need 
to shift to a qualitatively new level of teaching, where classical teaching methods will be combined with new methods in order to internationalize the professional training of highly qualified professionals.

By now a methodological aspect of internationalization (for each of the curriculum disciplines), according to Lyudmila V. Yarotskaya and Lilia V. Moiseenko, is still not properly provided, and this applies to both content and procedural components of training (Yarotskaya and Moiseenko, 2021). Thus, there is a lot of work to be done, which will consist of unifying curricula and teaching aids, standardizing the system of requirements, improving teachers' skills before a uniform educational environment is created.

At Kutafin Moscow State Law University (MSAL) training future legal professionals starts during the first year at university. The faculty of the Department of the State and Law teach students such disciplines as The Theory of the State and Law, The Legal System of the Russian Federation, etc. The Department of Practical Jurisprudence helps students choose a profession within the framework of the discipline Introduction to the Legal Profession.

Training of future advocates is mainly carried out by the faculty of the Department of Advocacy - both academics and practicing advocates - who use a variety of teaching methods to cope with the task entrusted to them in the context of distance learning due to the restrictive measures taken to combat the spread of the new coronavirus infection, on the one hand, and due to the digitalization of many processes in the higher education, on the other hand.

Taking into account that "advocacy is characterized by hundreds of subtleties, nuances, 'secrets', various techniques, methods, and technologies that come to a professional over the years" (Belova, 2005) and that "in contemporary conditions of the pressing need of the society to provide everybody with truly qualified legal assistance, advocates can no longer remain a custom-made product of prestigious education building up professionalism through years of experience" (Belova, 2005). The faculty of the Department of Advocacy are facing a rather complex task, namely, the task to train qualified future professionals who will be able to provide qualified legal assistance to all the people who need it. Therefore, in the context of modernization of educational 
process, the faculty of the Department of Advocacy are making every effort to ensure that "the precious experience gained over the years is perfectly integrated into new teaching methods" (Isayev, 2016) with due regard to the fact that "the biggest advantage of virtual reality technology in vocational education and practice teaching is that it can let participants experience the atmosphere and environment without going to the scene, and can have interactive experience" (Chen, 2021).

Indeed, each professor chooses his or her own method of teaching, based on the students' general level of training, the aims and objectives of the particular study course and the specifics of the legal resources. A partial transition to distance learning has also led to the following changes:

- the prevalence of active and interactive technologies in conducting class sessions (Andronova and Tarasenko, 2016) and the use of digital technologies in teaching and learning processes;

- the emphasis on practice-oriented types of independent extracurricular activities of students;

- the use of electronic resources in interim certification;

- the shift towards implementable practice-oriented projects in preparing Master's theses (e.g., a start-up as a Master's Thesis) (Blazheev and Egorova, 2020).

It is important to take into account all the changes mentioned above, as "in the context of global informatization of the state and society, in particular, the legal sphere, one of the main tasks of the Russian legal profession is to form a unified and integrated information environment" (Volodina and Gavrilov, 2020).

All of the above contributes to the creation and development of a common educational environment, which will allow, as mentioned above, to establish international cooperation in training students, develop other digital environments, including the creation of an integrated Russian information system of Advocacy.

\section{Using Webinars in a Teaching Process: Pros and Cons}

The year 2020 has fundamentally changed everyone's life. Both learners and the teaching staff had to adapt to distance learning as soon 
as possible. Professor of the Department of Philosophy and Sociology of Kutafin Moscow State Law University (MSAL) Aleksandr Yu. Ogorodnikov (Dr. Sci.) studied positive and negative experience of transition to distance learning in 2020 (Ogorodnikov, 2020). The analysis shows that most students consider video lectures that they can listen to at any time to be the most convenient form of lectures, while the faculty prefer webinars. Regarding practical classes, the vast majority of the students prefer to engage in a group project work, while the faculty again prefer webinars.

Despite the fact that webinars for the majority of the teaching staff were the most acceptable form of distance training, as the main drawback most of the respondents highlighted the impossibility to see and monitor all the participants connected to the webinar, as well as the inability to assess the involvement of each webinar participant.

The analysis conducted by Aleksandr Yu. Ogorodnikov also showed that most of the webinars at Kutafin Moscow State Law University (MSAL) in 2020 were held using the Zoom conference platform.

Thus, today students are getting used to training through distance learning technologies. Consequently, one of the objectives set before the faculty of the Department of Advocacy of Kutafin Moscow State Law University (MSAL), namely, to help students prepare for the qualification examination for the status of an advocate, has been achieved through the use of online webinars as a form of distance learning.

In spring 2020, Svetlana I. Volodina, Head of the Department of Advocacy of Kutafin Moscow State Law University (MSAL), invited the students of our university to join the webinars organized by the Russian Federal Bar Association. According to the statistics of the Russian Federal Bar Association, about 6,800 advocates join each regular broadcasting. In spring 2020, the majority of our country's population had to stay indoors following the lockdown restrictions, and this format of studying proved to be particularly in demand. The number of connections during this period was 9,000 advocates per day. These high rates indicate that webinars are in demand among advocates.

Having realized this demand, the Russian Federal Bar Association organized a course of webinars "Introduction to the Legal Profession" for trainees as well. The course consists of 10 days of webinars. According to 
statistics provided by the Russian Federal Bar Association, from 4,570 to 2,794 participants $(3,500$ on average) participated in the webinars daily.

The course of webinars "Introduction to the Legal Profession" was organized using distance learning technologies. Students had the opportunity not only to listen to lectures given by practicing lawyers, advocates and academics, including professors from the Department of Advocacy of Kutafin Moscow State Law University (MSAL), but also to ask questions and take tests devoted to the topics dealt with during the webinars. Initially, the webinar course was organized for advocates' trainees who were planning to take the qualification examination for the status of an advocate and the course was also offered to the students of Kutafin Moscow State Law University (MSAL) who willingly completed the tasks offered by the lecturers.

Despite the fact that "distance technologies are ideal for professional development, that is, just for such a form of learning as the presentation of new knowledge with a formed system of professional consciousness of a lawyer" (Zaitsev and Kravchenko, 2020), the study conducted by Aleksandr Yu. Ogorodnikov and analysis of statistical data of the Russian Federal Bar Association showed that webinars remain in demand for advocates' trainees and university students.

\section{Peculiarities of Practice-Oriented Training and Teaching Aids' Preparation in Digital Era}

\section{V.1. Interdisciplinary Approach to Training and Teaching Aids' Preparation}

Such disciplines as "Advocacy" and "Practical Skills of an Advocate" have been introduced into the curriculum of Kutafin Moscow State Law University (MSAL) for students. These disciplines include both lectures and practical classes. During the classes, the faculty of the Department of Advocacy familiarize students with the legislation on advocacy, practice and corporate acts of advocacy, assisting students in developing skills and abilities necessary to carry out their professional activities 
in the future. During the classes, the faculty members offer students to study real life cases, work with procedural documents and then they invite them to court hearings, so that the students have the opportunity to learn the basics of the legal profession.

In order to help students to acquire the knowledge and practice, as well as necessary skills by studying disciplines mentioned above, in 2018 the Department of Advocacy of Kutafin Moscow State Law University (MSAL) prepared a textbook "Practical Skills of an Advocate" (Korotkova, 2018). The manual proved to be in demand, and in the same 2018 the author of the study guide Polina E. Korotkova, Associate Professor of the Department of Advocacy, was awarded at the 3rd AllRussian Competition for the Best Scientific and Educational Publication "Akademus" in the category "Legal Literature." Due to the importance of such work, in 2019 based on the Department of Advocacy a case study guide was prepared for publication (Korotkova, 2019).

When studying the discipline "Advocacy," students are guided by the textbook "Advocacy" under the general editorship of the President of the Russian Federal Bar Association Yuriy S. Pilipenko (Pilipenko, 2018) as well as by the textbook "Advocacy in Russia" under the general editorship of Sergey S. Yuriev, a practicing advocate and holder of habilitation degree in Law. The textbook was prepared by a group of advocates and scholars, professors of the Department of Advocacy Polina E. Korotkova and Larisa A. Skabelina. The textbook was published in 2011 (Yuriev, 2011) and received the highest award as the most culturally significant project at the national award ceremony "Best Books and Publishers of the Year 2011" in 2012. Having received recognition among students as well, the textbook has been reprinted several times and it is now adapted for students of undergraduate and postgraduate studies.

As of academic year 2021/2022, applicants are being enrolled to a new master's program "Advocacy and Representation in Court" where students can also acquire the knowledge and skills they need for further professional activity. Among the disciplines taught, students can study the following courses: Professional Skills of an Advocate, Handling Civil Cases in Courts of First Instance and Courts of Controlling Authorities, 
Participation of an Advocate in Criminal Cases, Participation of an Advocate in the ECtHR.

Students also have an opportunity to master a foreign language as well. In order to cope with this task, students have at their disposal a rich collection of educational, methodological and scientific publications prepared by the faculties of Kutafin University and other higher education institutions. Thus, students interested in family law may be interested in the publication prepared on the basis of the AllRussian State University of Justice (RPA of the Ministry of Justice of Russia) by Sergei V. Agapov "Family Law: Textbook and Workshop for Universities." Students interested in such a category of cases as protection of intellectual property can resort to the textbook "Translation in Intellectual Property" by Viktoria V. Pikalova and Elena I. Rozanova (Pikalova and Rozanova, 2010).

At the same time, it should be borne in mind that not every student will be able to self-study the theory given in a textbook or a teaching aid. Students need clarifications of the provisions given in textbooks, their interpretation, and their correlation with the materials from other sources. As a result, both importance and responsibility of the practice-oriented departments, such as, for example, the Department of Advocacy and the Department of Legal Translation, are increasing, since the academic disciplines taught at such departments are initially focused on preparing students for a specific professional activity, e.g., to practice law in a foreign language.

\section{V.2. Digital Educational Environment and Opportunities for Students}

Further perspectives for the faculty research and publication work appear due to the introduction of Master's Programs taught in English. Such programs are aimed at both Russian-speaking students interested in high-quality professional education that gives them an opportunity to work internationally and foreign students interested in studying within the framework of the Russian legal system. Thus, in 2021, the Master's Program “Master of International Business" taught in English commenced in Kutafin Moscow State Law University (MSAL). 
In general, "the past few decades brought a number of significant changes into higher education, with some of the changes being driven by market forces such as globalization and technological advances making higher education a global and knowledge driven industry" (Tully and Avramenko, 2015, p. 152).

Much attention is now paid to international cooperation in the field of students' education, namely, to the development of network interaction between Kutafin Moscow State Law University (MSAL) and foreign partner universities, which makes it possible to run dualdegree programs. In particular, Kutafin University students currently have a unique opportunity to study International Law and Comparative Law within a dual-degree program. Theoretical and practical courses are taught in Moscow and in Switzerland at the Swiss Academy for International Law (the course is based on the Geneva educational module). Students completing this program are able to specialize in three languages in the following disciplines: Russian Federation law, European Union law, English law, intellectual property law, nuclear law, sports law and others. ${ }^{5}$

In addition to the opportunity to undertake an internship abroad, students are offered additional opportunities to master special disciplines in foreign languages within the walls of their Alma Mater as well. For this purpose, the Department of Legal Translation and the Department of English Language have been established at Kutafin Moscow State Law University (MSAL). The faculties of these departments train students for further law practice and academic activities, for work in international organizations and their representative offices operating on the territory of the Russian Federation, in various law firms where English language skills are required. These departments help students master legal disciplines in English by offering the following courses: "Practical Course of Legal Translation," "Practical Course of a Legal Foreign Language," "Translation of Legal Documents," etc., which is, of course, essential for a future lawyer and professional legal adviser. The pandemic concerns, however, encouraged the faculty to develop

5 For more information about Master's programs taught in English (in Geneva, Switzerland) see: https://www.msal.ru/content/obrazovanie/magistratura/. 
digitalized resources for the study courses in order not to distort the study process.

Moreover, students, interested in developing their foreign language skills can join different optional extracurricular activities that proved to be easily performed online, e.g., the Speaking Club where students guided by the faculty members can discuss various topics. The Speaking Club has been founded in order to boost students' communicative skills. Discussions devoted to the most urgent topics have already taken place within the framework of the Speaking Club: "Bioethics: Modern Challenges," "Three Approaches to Environmentalism. What are They?", etc.

Since 2018, MSAL students can choose optional courses offered by the Moot Courts Department. The Department was founded in 2018 on the basis of the Center for International Legal Competitions of Kutafin Moscow State Law University (MSAL). The Moot Courts Department became the first in the Russian Federation whose activities are associated with the introduction of various mock trials and moot courts projects in a foreign language into the educational process.

This is a new form of learning that has been called mooting. Pandemic concerns forced mooting teams participate in moot courts online. Moot courts organizers, teams and coaches had to unite their efforts to develop transparent and reliable mechanisms for online competitions.

Thus, a partial transition to distance learning facilitated creation and development of a common digital educational environment that allows us to widen international cooperation in the field of legal education.

\section{Teaching Professional Skills in a Law Clinic}

Law clinics are of great importance in the training of advocates. A significant contribution to the development of clinics in Russia was made by Professor Dmitriy I. Meyer (Kazan University, Russian Empire), who noted back in the 1860 s that "it is especially important in studying the dogma of law to acquaint students with the practical application of laws" (Shershenevich, 2003). 
Alaw clinic is "a structural subdivision of an educational organization [...] where practice-oriented programs for teaching professional skills are implemented, primarily by involving students in providing free legal aid to socially disadvantaged categories of citizens" (Markova and Samsonova, 2016).

The main objectives of the law clinic organization and operation can be divided into two groups. The first group includes educational objectives, such as:

a) educating students;

b) providing students with professional skills necessary to strengthen the practice-oriented component in the training of future lawyers;

c) professional orientation, adaptation and specialization of students;

d) forming professionally significant personal qualities in students;

e) developing students' high legal consciousness and understanding of social significance of jurisprudence and the role of lawyers in the society;

f) educating students in the spirit of respect for the rule of law, justice and human dignity.

The second group includes social objectives, such as:

a) creating conditions for the exercise of the right of citizens to legal assistance established under the Constitution of the Russian Federation;

b) developing a non-State system of free legal aid;

c) creating conditions for the exercise of the rights and freedoms of citizens, protection of their legitimate interests and enhancement of their social protection;

d) educating the population in law (Markova and Samsonova, 2016).

The main purpose of training at a law clinic is to prepare students for professional activity. The $P R O B O N O$ law clinic has also been established and operates at Kutafin Moscow State Law University (MSAL). MSAL students practicing in the clinic also have the opportunity to acquire knowledge and practice the skills necessary for their future professional activity, including the professional activity of an advocate. 
The PRO BONO law clinic that operates at Kutafin Moscow State Law University (MSAL) allows to "immerse students in professional legal activities long before they graduate" (Abrosimova, Voskobitova, Gutnikov, Lukyanova, et al., 2015, p. 17) involves the faculty of the Department of Practical Jurisprudence who can combine their professional activities working both in other departments of the University and for external organizations.

In January 2021, the Department of Practical Jurisprudence prepared and implemented the Young Professionals Project that consists of 22 unique courses drafted by practicing lawyers, including practicing advocates. "The Trial Lawyer" course, for example, aims at developing practical skills of a lawyer working in court in various categories of cases so that students could implement the theoretical knowledge already acquired during the studies. "The Trial Lawyer" program is designed in such a way that it allows students to gain skills in criminal, civil, commercial (arbitrazh) and administrative cases through direct interaction with lawyers. The course is supervised by advocates and professors of the Departments of Advocacy and Practical Jurisprudence of Kutafin Moscow State Law University (MSAL).

Another course run by advocates and the faculty of the Departments of Advocacy and Practical Jurisprudence of Kutafin Moscow State Law University (MSAL) is called "Law clinic: Basic Skills." This course consists of 12 sessions where students practiced skills needed to interview a principal, analyze a case and develop a case theory, give final advice to a principal, and subsequent sessions where students work with real principals. Work with the principals in Kutafin Moscow State Law University (MSAL) Law clinic proceeds as follows: having collected initial information, students prepare oral and written consultation under the guidance and supervision of the University's internship supervisor that is then sent for approval to a mentor in the relevant department. "The main task of a mentor is to check the quality of the student-lawyer's work beforehand, but not to interfere in the student-visitor contact..." (Abrosimova, Voskobitova, Gutnikov, Lukyanova, et al., 2015).

It is noteworthy that reception of principals and subsequent handling of the case of the principal and counselling of the principal can take place either remotely or in person, which is of particular 
importance in the current difficult circumstances. The form of interaction between a principal and law clinic trainees and a supervisor may vary according to the wishes of the participants and, among other things, the epidemiological situation.

Of course, not all students can join the law clinic, but only those who have been selected and have shown their knowledge of substantive and procedural law as well as their motivation and interest in this kind of work.

Thus, at present the law clinic is available for citizens outside Moscow by means of modern digital technologies. It should be noted that receiving and advising clients through digital technology has long been used in foreign countries, for example, in the Netherlands, where "the system of internet consultation is widely implemented in the practice of free legal advice" (Kilmyashkina, Mamonkina and Nemechkin, 2015). Of course, this is an additional opportunity both for citizens who, for whatever reason, do not have the opportunity to come to the law clinic and for trainees as they have the opportunity to advise a principal who is located abroad, including advising in a foreign language. In order to assist such trainees and other students who need English in their professional activity, the Institute of Legal Translation offers a unique program of further education: "Foreign Language for Professional Communication."

\section{Using a Courtroom for Additional Purposes}

Para 4.3 of the Order of the Ministry of Education and Science of the Russian Federation of August 13, 2020, No 1011 "On Approval of the Federal State Educational Standard of Higher Education Bachelor's Degree in the Field of Training 40.03.01 Jurisprudence" establishes requirements for substantive, technical, educational and methodological support of the Bachelor's program. In particular, the minimum list of logistical and methodological support of the Bachelor's program includes practicing mock trials and court-related activities in a courtroom. Such a courtroom is certainly available at Kutafin Moscow State Law University (MSAL). The main objectives of such a courtroom are: 
- to develop students' skills in working with procedural documents;

- to study the peculiarities of consideration and resolution of certain categories of court cases;

- to study the specifics of particular stages of court proceedings;

- to organize role-playing procedural games (mock trials);

- to develop judicial rhetorical skills (trial advocacy skills);

- to improve knowledge on substantive branches of Russian and foreign legislation.

Students take the opportunity to practice their persuasion skills by means of mock trials with great interest. For example, on April 21, 2018, the students of the Institute of Advocacy of Kutafin Moscow State Law University (MSAL) studied the case materials, including materials in a foreign language, and were able to play a mock trial with a jury. The mock trial relied on the US jurisdiction (the Manson Family Case). Gleb Glinka, an attorney and managing partner of IAB Glinka, Rubinstein \& Partners, who had been practicing in the United States for many years, acted as judge.

On 20 April 2019, students of the Institute of Advocacy and the Moscow Region Bar Association presented the second Model of American Trial (based on Truman Capote's "In Cold Blood"). Gleb Glinka, an attorney and managing partner of IAB Glinka, Rubinstein \& Partners, once again acted as the chief expert and the judge.

During the first semester this academic year, the final seminar in the form of a mock trial was held by Elena N. Kalacheva, an advocate and lecturer of the Department of Advocacy and the Department of Practical Jurisprudence. The class was held in the training courtroom. The mock trial was based on the novel "The Brothers Karamazov" by Fyodor M. Dostoevsky. ${ }^{6}$ Undoubtedly, it is a good experience for students, but it is not sufficient to fully immerse students into reality, to give students the opportunity to experience the legal profession from within.

Therefore, in our opinion, there is now a need to set up at Kutafin Moscow State Law University (MSAL), along with the mock trial courtroom, a specially equipped courtroom for real trials to help students

${ }^{6}$ For more information see: Introduction to the Profession: a Mock Trial. Available at: https://msal.ru/news/vvedenie-v-professiyu-igrovoy-sudebnyyprotsess-/ [Accessed 07.11.2021] (In Russ.). 
get accustomed to the process so that they can feel like participants of a court session.

The need for such a courtroom is driven by the fact that, as Prof. Lidiya A. Voskobitova said in her report made at the Scientific Conference "Modern Legal Education," "until we put a student in conditions of real practice, professional activity, he or she will not feel a need for skills. Until we create a situation where a student is aware of what knowledge and skills he or she lacks to solve a practical problem, to perform a professional action, he or she will not have a need for self-education" (Voskobitova, 2008, p. 31).

The setting up of a real courtroom will help "to adapt innovative tools for widespread use in Russian higher education practice" (Komarova, 2017). This would allow students intending to practice law to be present during court hearings as often as possible, to study the work of judges and court clerks, and to listen to the parties and their representatives acquiring the knowledge and practicing the skills necessary for their future profession.

There is already some experience in setting up such courtrooms. For example, Saratov State Law Academy's new training courtroom that was opened as early as 1 September 2015 hosted a visiting session of the 12th Arbitrazh Court of Appeal of Saratov Region. ${ }^{7}$

Students in such courtrooms will be able to witness work of a judge, an assistant judge, secretary of the court session and will be able to assess speeches of the parties' representatives. The very atmosphere in the courtroom, where real cases are heard, will encourage students to think not only about solving a case, but also to learn about a dress code for formal meetings and the rules of professional etiquette.

Such a courtroom should meet all the requirements for conducting trials, namely it should be equipped with modern computer equipment with audio-visual recording function, a deliberation room, as well as a room for visitors and other participants.

7 Court hearings were held in Saratov State Law Academy. Available at: http:// www.сгюа.pф/ru/info/news/item/4314-v-sgyua-proshli-sudebnye-zasedaniya [Accessed 07.11.2021] (In Russ.). 


\section{Conclusion}

Nowadays the Department of Advocacy, the Faculty of Legal Translation, the Department of English Language as well as other Departments of Kutafin Moscow State Law University (MSAL) have successfully incorporated elements of practice-oriented methods into the process of teaching including digital forms of teaching. Nevertheless, there are things to be done to provide stable functioning of the training system of preparing students for the qualification examination for the status of an advocate and subsequent legal practice in conditions of advocacy digitalization.

"An effective means of achieving the mass training of highly qualified advocates is to provide them with specialized professional training" (Belova, 2005), to teach students necessary knowledge and train necessary skills, in English as well. This training is available for students at Kutafin Moscow State Law University (MSAL) where the students intending to practice law in the future are familiarized with the legislation on advocacy and advocate's activity and the corporate acts of advocacy, and are prepared to take the qualification examination for the status of an advocate and to practice law.

Thus, the management of the University and the faculty of Kutafin Moscow State Law University (MSAL) have always done and continue to do their best to organize the training of highly professional, competitive specialists capable of working either in person or online both in the Russian Federation or abroad.

\section{References}

1. Abernathy, C.F., (2006). Law in the United States. American Casebook Series. USA: Thomson West.

2. Abrosimova, E.A., et al. (2015). Legal Clinic - Education Based on Practical Experience: Teaching Aid. Part I. Moscow: Legal Clinics Development Center (In Russ.).

3. Agapov, S.V., (2021). Family Law: Textbook and Workshop for Universities. Moscow: Yurait Publ (In Russ.). 
4. Andronova, T.A. and Tarasenko, O.A., (2013). Active and Interactive Forms of Classes for Bachelors and Masters. Juridical Education and Science, 2, pp. 33-37 (In Russ.).

5. Belova, N.M., (2005). Pedagogy of Training of Professional Advocates. Cand. Sci. (Pedagogy) Thesis. Moscow: Academy of Management of MIA of the Russian Federation (In Russ.).

6. Blazheev, V.V. and Egorova, M.A., (2020). Digital Law: Textbook. Moscow: Prospect (In Russ.).

7. Chen, S., (2021). Legal Practice Mode Based on Computer Technology. Journal of Physics: Conference Series, 1852(4), doi: 10.1088/1742-6596/1852/4/042014.

8. Demchenko, M.V., Gulieva, M.E., Larina, T.V., and Simaeva, E.P., (2021). Digital Transformation of Legal Education: Problems, Risks and Prospects. European Journal of Contemporary Education, 10(2), pp. 297-307, doi: 10.13187/ejced.2021.2.297 (In Russ.).

9. Egorova, M.A. and Minbaleev, A.V., (2021). The Main Features of the Introduction of Digital Innovative Methods in Educational Activities and the Significance of their Application for Teaching Foreign Students. Courier of Kutafin Moscow State Law University (MSAL), 1(77), pp. 27-38, doi: 10.17803/2311-5998.2021.77.1.027-038 (In Russ.).

10. Gladkikh, I.Y. and Yakushin, A.V., (2016). Systems of Automated Programming Testing in Educational Environment. Modern Problems of Science and Education, 3, pp. 326-336 (In Russ.).

11. Isayev, I.A., (2016). Stages of Establishment: All-USSR Correspondence Institute of Law - Moscow Law Institute - MSAL Kutafin Moscow State Law University (MSAL). Courier of Kutafin Moscow State Law University (MSAL), 9(25), pp. 8-23 (In Russ.).

12. Kilmyashkina, D.V., Mamonkina, A.A., and Nemechkin, V.N., (2015). International Experience of Organizing Clinical Legal Education. Ogaryov-Online, 5(46), p. 7 (In Russ.).

13. Kolotov, A.F. and Skuratov, I.V., (2014). Methodology of Teaching Law: Textbook for Master's Students studying "Jurisprudence". Orenburg: Universitet Publ (In Russ.).

14. Komarova, V.V., (2017). The Legal Education Reform. In: Issues of Legal Education: collected volume of scientific papers. Vol. 1. Moscow: Original-maket Publ (In Russ.). 
15. Korotkova, P.E., (2018). Practical Skills of an Advocate: Study Guide for Bachelor Students. Moscow: Norma: INFRA-M Publ (In Russ.).

16. Korotkova, P.E., (2019). Practical Skills of an Advocate: Textbook for Bachelor Degree Students. Moscow: Norma INFRA-M (In Russ.).

17. Lyubshev, Yu.F., (2003). The Course of Advocacy Law. Moscow: Profobrazovanie Publ (In Russ.).

18. Markova, T.Yu. and Samsonova, M.V., eds., (2016). Professional Skills of a Lawyer: Textbook for Academic Bachelor Students. Moscow: Yuright Publ (In Russ.).

19. Ogorodnikov, A., (2020). Institutionalization of Distance Learning Technologies in a Law School. Kutafin University Law Review, 7(2), pp. 214-244, doi: 10.17803/2313-5395.2020.2.14.214-244.

20. Pikalova, V.V. and Rozanova, E.I., (2010). Translation in Intellectual Property. Textbook for Students of Higher Education Institutions. Moscow: Akademiya Publ (In Russ.).

21. Pilipenko, Yu.S., ed., (2018). Advocacy: Textbook for Undergraduate Students. 2nd ed. Moscow: Prospekt (In Russ.).

22. Shershenevich, G.F., (2003). Science of Civil Law in Russia (Classics of Russian Civilistics). Moscow: Statut Publ (In Russ.).

23. Shevchenko, O.I., Volkov, M.A., and Prystavka, A.S., (2018). Methods and Forms of Students' Education. International Journal of Humanities and Natural Sciences, 5(1), pp. 106-112 (In Russ.).

24. Tully, N. and Avramenko, A., (2015). Au fait law placements: An emerged reality or a popular trend in contemporary education? Higher Education, Skills and Work-based Learning. 5(2), pp. 152-167, doi: 10.1108/HESWBL-05-2014-0016.

25. Volodina, S.I. and Gavrilov, S.N., (2020). Digital Transformation of the Russian Legal Profession. Revista Inclusions, 7, pp. 2-10. Available at: https://revistainclusiones.org/index.php/inclu/article/view/1494 [Accessed 07.11.2021].

26. Voskobitova, L.A., (2008). Proceedings of the Scientific Conference [October 17, 2006] "Modern Legal Education." Moscow: Gubkin University (In Russ.).

27. Yarotskaya, L.V. and Moiseenko, L.V., (2021). Training of an International Lawyer to Work in the International Legal Environment: 
A Linguo-Didactic Aspect. Public International and Private International Law, 1, pp. 41-44, doi: 10.18572/1812-3910-2021-1-41-44 (In Russ.). 28. Yarotskaya, L.V., (2013). Lingvo-didactic Bases of Internationalization of Professional Training (Foreign Language, Non-linguistic Higher Education Institution). Cand. Sci. (Pedagogy) Thesis. Moscow: Moscow State Linguistic University (In Russ.).

29. Yuriev, S.S., ed., (2011). Advocacy in Russia. Moscow: Yuright Publ (In Russ.).

30.Zaitsev, O.V. and Kravchenko, A.A. (2020). Professor D.I. Meyer's Heritage in Modern Law Education (Experience of the School of Law IPACS RANEPA). Herald of Civil Procedure, 10(1), pp. 22-38 (In Russ.).

\section{Information about the Authors}

Polina E. Marcheva (Korotkova), Cand. Sci. (Law), Senior Lecturer, Department of Advocacy; Department of Practical Jurisprudence, Kutafin Moscow State Law University (MSAL), Moscow, Russia

9 Sadovaya-Kudrinskaya ulitsa, Moscow 125993, Russia

p.korotkova@mail.ru

ORCID: 0000-0002-6899-1950

Elena A. Kholina, Lecturer, Department of Social and Humanitarian Disciplines and History of Law, Moscow Metropolitan Governance Yury Luzhkov University (MMGU), Moscow, Russia

28 ulitsa Sretenka, Moscow 107045, Russia

kholinaea@gmail.com

ORCID: 0000-0003-4098-6284 